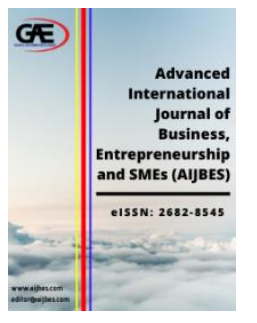

\author{
ADVANCED INTERNATIONAL JOURNAL OF \\ BUSINESS, ENTREPRENEURSHIP AND SMES \\ (AIJBES) \\ www.aijbes.com
}

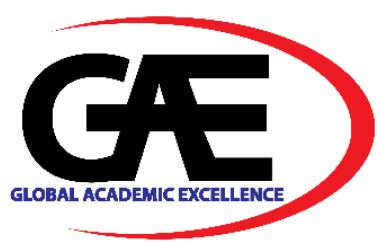

\title{
PROPOSED MODELS FOR CSR MARKETING COMMUNICATIONS ON FACEBOOK BASED ON COMPANY - CAUSE FIT AND CONSUMER RESPONSES
}

\author{
Ronnie Pangan ${ }^{1 *}$, Jaehak Shim ${ }^{2}$ \\ 1 The Graduate School, University of Santo Tomas, Manila Philippines \\ Email: ronnie.pangan.gs@ust.edu.ph \\ 2 The Graduate School, University of Santo Tomas, Manila Philippines \\ Email: jhshim@ust.edu.ph \\ * Corresponding Author
}

\section{Article Info:}

Article history:

Received date: 08.04.2021

Revised date: 28.04 .2021

Accepted date: 06.06.2021

Published date: 15.06.2021

\section{To cite this document:}

Pangan, R., \& Shim, J. (2021). The Proposed Models for CSR Marketing Communications on Facebook Based on Company-Cause Fit and Consumer Responses. Advanced International Journal of Business, Entrepreneurship and SMEs, 3 (8), 98-118.

DOI: $10.35631 / A I J B E S .38007$.

This work is licensed under $\underline{\mathrm{CC} B Y} 4.0$

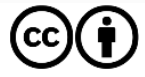

\begin{abstract}
:
Businesses should use Corporate Social Responsibility (CSR) marketing communications to show genuine support for stakeholders affected by the Covid19 pandemic. Two forms of CSR marketing communications were focused on: cause-related marketing (CRM) and cause sponsorship (CS). This research looked into how CRM and CS impact customer responses to: a) like/join the company's Facebook page, b) exchange CSR activities through eWOM (electronic word-of-mouth), and c) intention to buy the company's products and services (purchase intention). The company-cause fit was the dependent variable that was tested against the three responses. A survey-based within-subjects experiment of CRM and CS x 2 (good fit / bad fit) was conducted on active Facebook users aged 18 to 64 years old. Ten (10) preselected firms from the Philippines' Top 30 Businesses were listed, These companies released both CRM and CS Facebook posts. The CRM posts were shown to half of the sample size $(n=136)$, while the CS posts were shown to the other half $(n=136)$ and rated by a questionnaire. This research suggested models based on regression analysis and modeling that would advise companies how to better conduct CRM and CS online operations in order to maximize investments, especially during periods of crisis like the Covid19 pandemic.
\end{abstract}

Keywords:

CSR, CRM, CS, Company-Cause Fit, Liking, eWOM, Purchase Intention 


\section{Introduction}

Corporate social responsibility (CSR) is described as social or environmental corporate operation that goes beyond the laws and regulations of the organization (Kitzmueller \& Shimshack, 2012). According to He and Harris (2020), the Covid-19 pandemic presented businesses with an outstanding chance to move to real CSR and committed to addressing urgent global social problems. A more optimistic prediction was that the Covid19 pandemic would hasten post-pandemic CSR (He \& Harris, 2020).

CSR experts have realized that certain CSR communications need something more than just informing the public about them; community participation is required for the implementation, as the public is either required as program supporters or is the ultimate target audience whose behavior the program seeks to influence (Sun, Zhang, \& Abitbol, 2019).

The current research focused on two categories of CSR marketing communications, namely cause-related marketing (CRM) and cause sponsorship (CS). Given the current Covid19 pandemic, the company-cause fit of CRM and CS communications was contrasted and studied in terms of how they impact customer reactions, specifically liking/joining FB pages, sharing through eWOM, and purchasing intention.

\section{Scope and Limitation of Study}

This study looked into how consumers respond to CSR marketing messages on Facebook. This analysis concentrated on ten firms from the top 30 largest publicly traded entities in the Philippines in 2019, as calculated by the Philippine Stock Exchange Index (PSEi). For a sixmonth cycle, the subjects of the study were the CSR marketing messages presented on Facebook by the ten chosen firms (from March, 2020 to August, 2020). The CSR posts chosen are those related to the Covid-19 pandemic and those that are plain enough for audiences to distinguish between CRM and CS events with little or no stimuli.

In terms of participants, this research would not involve the whole population of Facebook users, which ranges from 13 to 17 years old to over 65 years old. According to Statisica.com (2020), the entire populace of Facebook users is divided into seven groups: 13 to 17, 18 to 24, 25 to 34,35 to 44,45 to 54,55 to 64 , and 65 and up. This analysis will exempt the age ranges of 13 to 17 and 65 and up because they either are not yet working or are retired. Throughout this analysis, only 5 age ranges from 18 to 64 would be included.

\section{Literature Review}

\section{CSR Marketing Communications}

According to Turkel and Akan (2015), CSR marketing communication is the process of anticipating stakeholders' perceptions, expressing CSR policy, and maintaining various organizational marketing communication tools (both offline and online) designed to provide legitimate and transparent information about a company's or brand's integration of business operations, social and environmental concerns, and interactions with stakeholders. To accomplish the aforementioned corporate goals, businesses use marketing communication tools such as ads, product labeling, media relations, CSR reports, and websites. While advertising and public relations are considered open communication channels, CSR reports and websites are considered covert communication channels. 


\section{Cause-Related Marketing (CRM)}

Cause-related marketing is a form of promotional activity in which a company endorses a societal or humanitarian cause, usually in conjunction with its goods and services as a package or tie-in. Cause-related messaging is often conducted as an advertising effort in collaboration with a foundation or non-profit agency dedicated to a particular social cause (Beise-Zee 2013). This is a campaign technique under which a business's proceeds are attached to a charity or other voluntary entity to which a portion of sales income is contributed. According to Human (2016), CRM is characterized as "the method of formulating and executing marketing practices that are defined by the company's offer to donate a certain sum to a particular cause when customers participate in revenue-providing exchanges that meet organizational and individual goals". CRM is a marketing activity in which companies and organizations (or causes) create a partnership for shared gain in order to enter a new market, product, or service. It is a strategy for assisting and financing the settlement of current societal issues while still following core corporate goals.

\section{Cause Sponsorship (CS)}

The CS initiative on social media supports an organization's monetary and product contributions to a charity over a given period of time, normally by naming the company as the cause's official donor (Jeong, 2011). The definitions of advertising have evolved over time as sponsorship has grown (Markova \& Rosenberger, 2013). Sponsorship is described as the provision of financial or in-kind assistance to a business organization in order to help it meet its objectives. According to Jeong (2011), if the affiliate agency is an NGO, users are more inclined to view the socially favorable advertisements on the cause sponsorship in a positive light. Cause sponsorship differs from CRM in that the sponsorship is charged before every consumer-oriented campaign is launched. Consumer sales are not required for charitable donations, and they have no correlation on the amount donated (Chang, 2012).

\section{Company-Cause Fit}

According to research on social cause ads, perceived company-cause fit, described as the degree to which a sponsored social cause is linked to the sponsorship firm's core business, plays a significant role in influencing viewers' reactions to social cause communications (Kim, et al, 2015). "The supposed conformance between a societal problem and the business of a company," is referred to as fit. Zasuwa (2017) performed an evaluation that stated that company-cause fit affects consumers more favorably in relation to CSR interventions when an enterprise with a good image participates very much in a cause (i.e. when the firm gives at least some goods). When an organization merely makes a monetary donation to the beneficiaries (i.e. poor participation), the fit results are considerably less significant.

\section{Electronic Word-of-Mouth (eWOM)}

Electronic word-of-mouth, according to Bryum (2014), is viral messaging that a company may utilize by sending the right message to the right messengers in the right place. EWOM is "any favorable or derogatory remark rendered regarding a product or company by potential, present, or former consumers that is made accessible to a plethora of individuals and organizations through the internet," according to Mohammed et al (2015). It is no longer possible to cater to users who have common views and values, thanks to the widespread use of technological advancements and Web 2.0. Crafting social networks and communicating with peers are two of the most popular practices among SNS users (Fatma, et al 2020). Users consider the concepts perpetuated in the channels through eWOM as highly reliable in this regard since they are based on connections (Colleoni, 2013). CSR participation is accomplished as customers actively 
Volume 3 Issue 8 (June 2021) PP. 98-118

DOI 10.35631/AIJBES.38007

address a company's CSR practices with others (Bhattacharya and Sen, 2004). Companies are participating in CSR in order to retain a successful and socially conscious profile (Fatma, et al 2020).

It is now well accepted that eWOM does have a major impact on consumer purchasing intentions. Social networking sites (SNS), such as Twitter, also made it easy to communicate thoughts with other users of the network. Consumers have responded more positively to eWOM (Erkan, 2016). According to the findings of a CSR study performed by Abner (2019), there is a favorable association regarding disposition toward purchasing and the purpose of purchasing ethical clothing. It was also discovered that positive eWOM culminated in a positive outlook toward the brand and a desire to purchase. The research contributes to our understanding of the efficacy of social media in informing consumers about companies' CSR practices, the effects of supportive eWOM, and the attributes of related goods (Abner, 2019).

Research by Martinez et al (2020) found that the relevance of data consistency, self-disclosure, and trust in Facebook have a significant impact on eWOM's intentions to share and react to CSR reports. Similarly, this study indicates that the value of readily available content has an effect on eWOM intentions, which is compatible with previous research (Lee \& Koo, 2015; Serra \& Salbi, 2014). This study has found that source reliability has a positive impact on information.

\section{Theoretical Framework}

\section{CSR Marketing Communications}

According to Turkel and Akan (2015), CSR marketing communication is the process of anticipating stakeholders perceptions, expressing CSR policy, and maintaining various organizational marketing communication tools (both offline and online) designed to provide legitimate and transparent information about a company or brand's integration of business operations, social and environmental concerns, and interactions with stakeholders. To accomplish the aforementioned corporate goals, businesses use marketing communication tools such as ads, product labeling, media relations, CSR reports, and websites. While advertising and public relations are considered open communication channels, CSR reports and websites are considered covert communication channels.

\section{Cause-Related Marketing (CRM)}

Cause-related marketing is often coordinated as a promotional campaign in conjunction with a foundation or nonprofit agency that pursues a particular social cause. According to Human (2016), CRM is characterized as "the method of formulating and executing marketing practices that are defined by the company's offer to donate a certain sum to a specific cause when consumers engage in revenue-providing exchanges that fulfill organizational and individual objectives."

\section{Cause Sponsorship (CS)}

The CS initiative on social media encourages a company's monetary and product contributions to a cause over a specific time span, usually by naming the brand as the official supporter of the cause (Jeong, 2011). Cause sponsorship differs from CRM in that the sponsorship charge is charged before any consumer-oriented campaign relevant to the cause is launched. Consumer sales are not required for charitable contributions, and they have little bearing on the value of the donation (Chang, 2012). 


\section{Company-Cause Fit}

As per research in social cause marketing, perceived company cause fit, described as the degree to which a sponsored social cause is relevant to the core sector of the sponsorship firm, plays an important role in influencing viewers' reactions to social cause messages (Kim, et al, 2015). The term "fit" refers to "the supposed congruity between a social problem and the business of an organization."

\section{Liking Facebook Pages}

Facebook consumers click the Like button on the company's Facebook profile and agree to receive alerts from their news outlet (Gingerich 2015). The relationship begins with a "Like" on the Facebook profile. The key contribution of Treviño's (2016) paper is the suggestion that some of the previously established dimensions in the position of CSR in consumer choices, as well as the success of general advertising in social networking, will more likely be calculated by the model's independent variable, customer intentions to enter the brand page with CSR interventions (Oberseder et al., 2011).

\section{Electronic Word-of-Mouth (eWOM)}

Electronic word-of-mouth, according to Bryum (2014), can be described as viral messaging that a company can use by sending the right message to the right messengers in the right setting. EWOM is described as "any positive or negative statement made about a product or company by potential, present, or former customers that is made accessible to a significant number of people and organizations through the web" (Byrum 2014).

\section{Purchase Intention}

Purchase intention is described as the customer's effort to acquire the brand or take some reasonable action associated with the purchase. It is the intentional planning of the intervention phase, the actual buyer response mechanism (Human, 2016). While CSR is critical, studies have yet to validate how CSR methods influence customers' buying intentions, according to Hameed et al (2018). Customers like firms that practice CSR; it serves as a defense and protects businesses from unintended harmful incidents.

\section{Theoretical Framework}

This research is focused on two theoretical perspectives: the theory of impression management (Jeong et al, 2013) and the theory of the model of effects hierarchy (Chung, 2019).

According to the concept of impression management, companies employ impression management tactics to manage their image and improve a positive opinion towards their customers, and firms are forced to embrace principles of direct or implicit impression management in a cultural context (Esen \& Ozsozgun, 2018). 


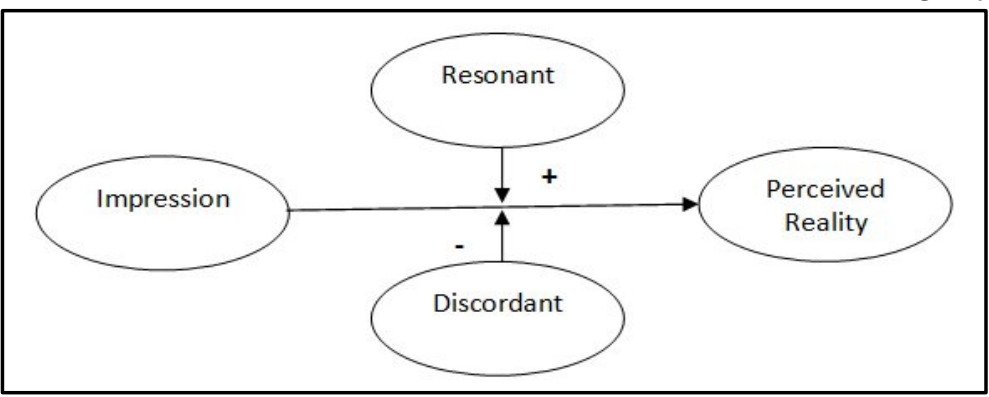

Figure 1: Impression Management Theory

Meanwhile, the hierarchy of effects model asserts that users do not immediately progress from disinterested to convinced customers. Clients instead view transactions through a multi-stage phase, with the transaction itself acting as the final piece. Perceptions of CSR are characterized as a collection of expectations (i.e. cognitive stage) that, in turn, cause consumer affective responses (i.e. affective stage) that, in turn, affect customer actions (i.e. conative stage), such as suggestion and repurchase (Vlachos, 2012).

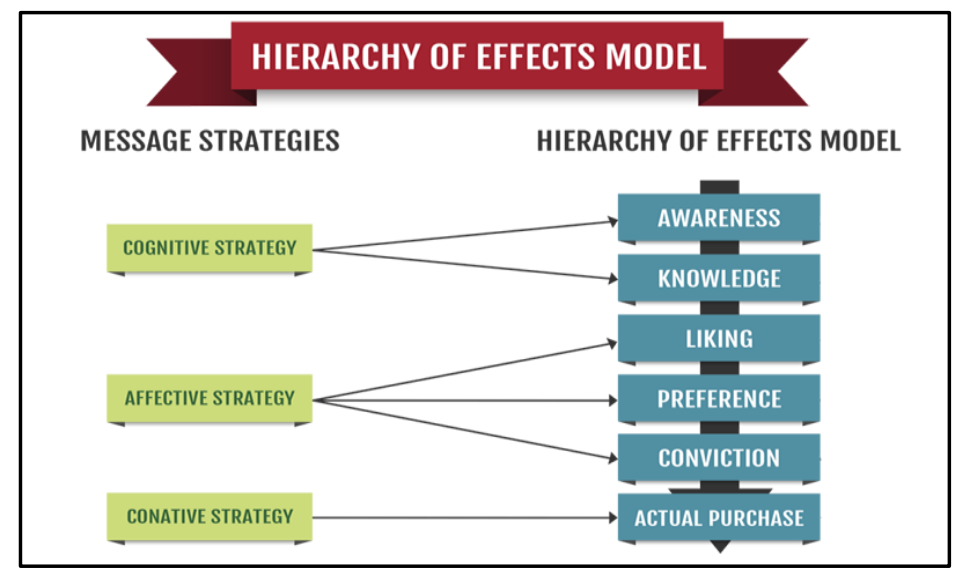

Figure 2: Hierarchy of Effects Model

\section{Diagrammatic Framework}

This study's conceptual framework was based on impression management theory (Ozsozgun, Esen, \& Kaliskan, 2018) and the hierarchy of effects model (Pérez \& del Bosque, 2015). 
Volume 3 Issue 8 (June 2021) PP. 98-118 DOI 10.35631/AIJBES.38007

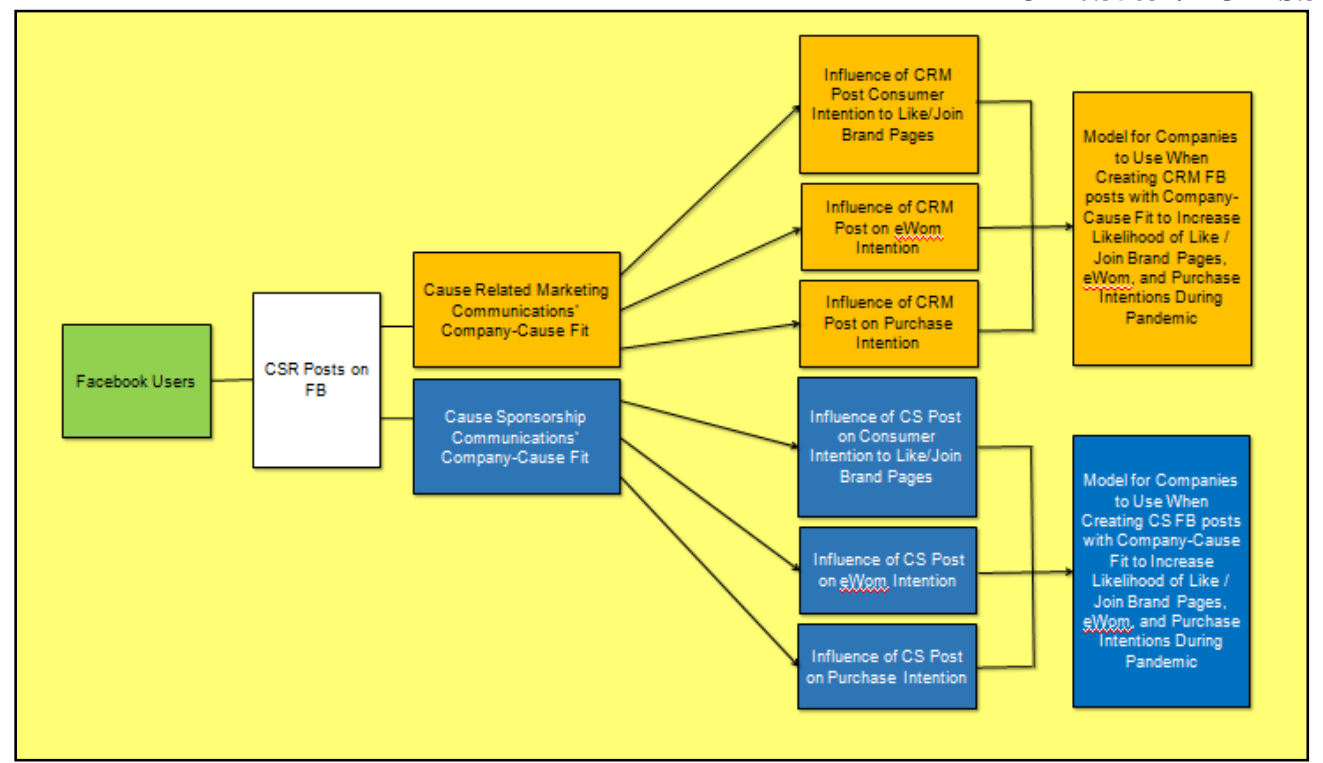

Figure 3. The Diagrammatic Framework

The current research suggested two impression management methods: overt and covert techniques, and used impression management theory to clarify the effectiveness of the two styles of CSR marketing communications. Consumers, for example, attempted to integrate aspects of their own abilities or qualities (e.g., affability, competence) for the immediate approach (e.g., ingratiation, self-advancement) to look desirable and capable to others (Jeong 2011).

The principles of hierarchy of effects are widely used in the study of buyer responses to CSR advertising (Pérez \& del Bosque, 2015). These consumer responses are based on the three categories in the Hierarchy of Effects model: cognitive (liking FB pages), affective (sharing through eWOM), and conative (purchase intent).

The following theories were raised and tested:

Ho1: During the Covid19 pandemic, there is no statistically sound difference regarding CRM and CS posts as used in CSR marketing communications on Facebook.

Ho2: During the Covid19 pandemic, CRM and CS posts on Facebook had no major impact on customers' intentions to an organization in terms of liking / joining brand accounts, eWOM purpose, and buying intentions.

Ho3: The impact of CSR marketing communications types on customer intentions to a brand will not be driven by the CSR company-cause fit.

\section{Methodology}

\section{Research Design}

To accomplish the research goals, quantitative testing was included in this review. In the analysis, there were two dependent variables: CRM company-cause fit and CS company-cause fit. These were compared to three customer responses: intentions to like/enter brand pages, sharing through eWOM, and intention to purchase.

Exploratory testing, primarily a descriptive-correlational analysis research design, was used in the study to distinguish variations between variables. The CRM Company-Cause Fit and the 
Volume 3 Issue 8 (June 2021) PP. 98-118 DOI 10.35631/AIJBES.38007

CS Company-Cause Fit were contrasted to see whether there was a statistically relevant gap across the COVID19 pandemic. Second, CRM and CS company-cause Fit was compared to three factors: intentions to like/join brand pages, sharing through eWOM, and intention to purchase, to see whether there was a meaningful connection between them.

\section{Sampling Procedure and Participants}

Ten (10) of the thirty (30) firms on the list were purposefully chosen based on five principles. First, there was the presence of both forms of CRM and CS posts on Facebook that were related to the Covid-19 pandemic. Second, posts must be rendered within six months, from March 1, 2020 to August 31, 2020. Third, the articles were of good standard, indicating that they were published by a communicator with a history in CSR. Fourth, the CRM and CS posts must be distinguishable from one another and readily identifiable as either a CRM or a CS post. Fifth, and finally, the businesses must come from a variety of industries in order to have a fair portrayal of the industries in the Philippines. Table 1 detailed the ten organizations that were listed.

\section{Table 1: Ten Selected Companies to be Part of Quantitative Study}

\section{Company Name Businesses \\ CRM Title\& Description \\ CS Title\& Description}

\begin{tabular}{|c|c|c|c|}
\hline $\begin{array}{l}\text { Ayala } \\
\text { Corporation }\end{array}$ & $\begin{array}{l}\text { Real Estate and } \\
\text { Hotels, Malls, } \\
\text { Telecommunic } \\
\text { ations, Water } \\
\text { infrastructure, } \\
\text { Power } \\
\text { Generation, } \\
\text { BPO. }\end{array}$ & $\begin{array}{l}\text { Be a \#BuyAni-Ayala } \\
\text { helped vulnerable } \\
\text { sectors of society such } \\
\text { as farmers by training } \\
\text { them with alternative } \\
\text { sources of livelihood. }\end{array}$ & $\begin{array}{l}\text { Ayala Sponsors PioPioe- } \\
\text { Learning Fundraiser - } \\
\text { Ayala sponsored PioPio's } \\
\text { e-Learning that benefited } \\
\text { students by providing } \\
\text { devices. }\end{array}$ \\
\hline $\begin{array}{l}\text { Aboitiz Equity } \\
\text { Ventures, Inc. } \\
\text { (AEV) }\end{array}$ & $\begin{array}{l}\text { Power } \\
\text { Generation, } \\
\text { Banking and } \\
\text { Financial } \\
\text { Services, Food }\end{array}$ & $\begin{array}{l}\text { \#OneAboitiz in Action } \\
\text { - Aboitiz was able to } \\
\text { raise P370 million }\end{array}$ & $\begin{array}{l}\text { Heroes } 2021 \text { with } \\
\text { Thames international } \\
\text { School-benefited DepEd } \\
\text { public school teachers by } \\
\text { providing them with the } \\
\text { means for online teaching. }\end{array}$ \\
\hline $\begin{array}{l}\text { Alliance Global } \\
\text { Group, Inc. } \\
\text { (AGI) }\end{array}$ & $\begin{array}{l}\text { Food } \\
\text { \&Beverage, } \\
\text { Gambling, } \\
\text { Real Estate }\end{array}$ & $\begin{array}{l}\text { M Safe Crew - } \\
\text { equipped employee's } \\
\text { with safety protocols } \\
\text { to provide a safe } \\
\text { environment for } \\
\text { customers and } \\
\text { themselves. }\end{array}$ & $\begin{array}{l}\text { Kindness Kitchen } \\
\text { Supports World Vision- } \\
\text { McDonald's, through their } \\
\text { CSR arm Kindness } \\
\text { Kitchen, sponsored World } \\
\text { Vision in their Covid-19 } \\
\text { emergency response. }\end{array}$ \\
\hline $\begin{array}{l}\text { BDO Unibank, } \\
\text { Inc, (BDO) }\end{array}$ & $\begin{array}{l}\text { Banking and } \\
\text { Finance }\end{array}$ & $\begin{array}{l}\text { Peso for Peso } \\
\text { Donation Drive - } \\
\text { BDO Foundation } \\
\text { committed to } \\
\text { matching every peso } \\
\text { donated to them that } \\
\text { was for under }\end{array}$ & $\begin{array}{l}\text { BDO Supports to } \\
\text { RapidPass \& ReleifAgad } \\
\text { Projects- BDO assisted } \\
\text { these two CSR projects by } \\
\text { sharing financial } \\
\text { assistance. }\end{array}$ \\
\hline
\end{tabular}


Volume 3 Issue 8 (June 2021) PP. 98-118 DOI 10.35631/AIJBES.38007

\begin{tabular}{|c|c|c|c|}
\hline \multicolumn{4}{|c|}{ privileged sectors. } \\
\hline $\begin{array}{l}\text { DMCI Holdings, } \\
\text { Inc. (DMC) }\end{array}$ & $\begin{array}{l}\text { Construction, } \\
\text { Real Estate } \\
\text { Development, } \\
\text { Mining, and } \\
\text { Power } \\
\text { Generation } \\
\end{array}$ & $\begin{array}{l}\text { Covid19 } \\
\text { Precautionary } \\
\text { Measures - DMCI } \\
\text { shared precautionary } \\
\text { guidelines to keep } \\
\text { their employees safe. }\end{array}$ & $\begin{array}{l}\text { Furry Friends at PAWS - } \\
\text { DMCI sponsored the } \\
\text { meals and maintenance of } \\
\text { dogs at the PAWS center. }\end{array}$ \\
\hline $\begin{array}{l}\text { Jollibee Foods, } \\
\text { Corporation }\end{array}$ & $\begin{array}{l}\text { Local and } \\
\text { International } \\
\text { Fast Food } \\
\text { Operations }\end{array}$ & $\begin{array}{l}\text { Jollibee FoodAID - } \\
\text { as of May 26, 2020, } \\
\text { the Jollibee Group } \\
\text { Foundation donated } \\
\text { P220 million worth of } \\
\text { meals. }\end{array}$ & $\begin{array}{l}\text { Financing Solutions for } \\
\text { Social Protection in } \\
\text { Covid-19 Response and } \\
\text { Recovery Webinar - } \\
\text { Jollibee sponsored the } \\
\text { Asian Philanthropy } \\
\text { Venture Network (APVN) } \\
\text { webinar. }\end{array}$ \\
\hline Petron & $\begin{array}{l}\text { Oil Refinery } \\
\text { and Marketing }\end{array}$ & $\begin{array}{l}\text { \#FuelHope -Petron } \\
\text { Value Card Points } \\
\text { were donated and } \\
\text { exchanged for cash. } \\
\text { Was able to } \\
\text { accumulate P1.6 } \\
\text { million. }\end{array}$ & $\begin{array}{l}\text { Petron Fuels Hyundai } \\
\text { Asia- Petron joined } \\
\text { Hyundai's campaign of } \\
\text { providing frontliners with } \\
\text { gasoline. }\end{array}$ \\
\hline $\begin{array}{l}\text { Manila Electric } \\
\text { Company (MER) }\end{array}$ & $\begin{array}{l}\text { Power } \\
\text { Generation, } \\
\text { Contracting, } \\
\text { Renewable } \\
\text { Energy }\end{array}$ & $\begin{array}{l}\text { \#KeepingTheLightsO } \\
\boldsymbol{n} \text { - Meralco provided } \\
\text { to subscribers a 30- } \\
\text { day extension bill. }\end{array}$ & $\begin{array}{l}\text { SBMA \& Philippine Red } \\
\text { Cross Sponsorship - } \\
\text { Meralco sponsored Subic } \\
\text { Bay Metropolitan } \\
\text { Authority and Philippine } \\
\text { Red Cross's testing } \\
\text { facility. }\end{array}$ \\
\hline $\begin{array}{l}\text { SM Investments, } \\
\text { Corporation }\end{array}$ & $\begin{array}{l}\text { Retail, } \\
\text { Financial } \\
\text { Services, Real } \\
\text { Estate }\end{array}$ & $\begin{array}{l}\text { \#SMCares - SM } \\
\text { Foundation donated } \\
\text { several medical } \\
\text { equipment to } \\
\text { frontliners. }\end{array}$ & $\begin{array}{l}\text { Bata Shoes Global } \\
\text { Donation Program - SM } \\
\text { sponsored 1,800 pairs of } \\
\text { shoes for Bata's global } \\
\text { donation drive that were } \\
\text { given to PGH. }\end{array}$ \\
\hline PLDT (TEL) & $\begin{array}{l}\text { Diverse } \\
\text { Telecommunic } \\
\text { ations Services }\end{array}$ & $\begin{array}{l}\text { 30-Day Payment } \\
\text { Extension - When the } \\
\text { whole island of Luzon } \\
\text { was in lockdown, } \\
\text { PLDT announced an } \\
\text { extension of } 30 \text { days } \\
\text { for all subscribers. }\end{array}$ & $\begin{array}{l}\text { PGH 24/7 Covid-19 } \\
\text { Hotline - Philippine } \\
\text { General Hospital and } \\
\text { PLDT created a } 24 / 7 \\
\text { hotline for Covid19 } \\
\text { concerns. }\end{array}$ \\
\hline
\end{tabular}

The sample size for the quantitative component (experimental) of the analysis was determined using Cochran's formula. The formula's components were as follows: e is the optimal degree of precision (or margin of error), $\mathrm{p}$ is the average proportion of the population of the attribute in question, $\mathrm{q}$ is $1-\mathrm{p}$, and the $\mathrm{z}$ value (according to the $\mathrm{z}$ table) is 1.75 at a confidence level of $90 \%$. The calculated sample size is 272 people. Facebook users between the ages of 18 and 64 
Volume 3 Issue 8 (June 2021) PP. 98-118

DOI 10.35631/AIJBES.38007

were targeted. Table 2 revealed a recomputed demographic that excludes the 13 to 17 and 65 and older age categories. The rationale for this change was that purchasing intent is one of the consumer responses being evaluated.

Table 2: Recomputed population using stratified sampling technique for active FB users from 18 to 64 years old age segments

\begin{tabular}{|c|c|c|c|c|c|c|}
\hline $\begin{array}{c}\text { Age } \\
\text { Segments } \\
\text { Identified } \\
\text { for } \\
\text { Sampling } \\
\text { Size }\end{array}$ & $\begin{array}{c}\text { Total } \\
\text { Population } \\
\text { from } 13 \text { to } \\
65+\end{array}$ & $\begin{array}{l}\text { Percentage } \\
\text { According to } \\
\text { Population } \\
\text { of } 13 \text { to } 65+ \\
\text { Years Old }\end{array}$ & $\begin{array}{c}\text { Population } \\
\text { size of } 18 \text { to } \\
64\end{array}$ & $\begin{array}{c}\text { Percentage } \\
\text { as } \\
\text { Compared } \\
\text { to } \\
\text { Population } \\
\text { of } 18 \text { to } 64 \\
\text { Years Old }\end{array}$ & $\begin{array}{c}\text { Sample } \\
\text { Size }\end{array}$ & $\begin{array}{l}\text { No. of } \\
\text { Respondents } \\
\text { Required by } \\
\text { Age Segment }\end{array}$ \\
\hline $\begin{array}{c}18 \text { to } \\
24\end{array}$ & & 32.8 & $23,999,760$ & 37.36 & & 102 \\
\hline $\begin{array}{c}25 \text { to } \\
34\end{array}$ & & 30.1 & $22,024,170$ & 34.28 & & 93 \\
\hline $\begin{array}{l}35 \text { to } \\
44\end{array}$ & $73,170,000$ & 13.9 & $10,170,630$ & 15.83 & 272 & 43 \\
\hline $\begin{array}{c}45 \text { to } \\
54\end{array}$ & & 7.2 & $5,268,240$ & 8.20 & & 23 \\
\hline \multirow[t]{2}{*}{$\begin{array}{l}55 \text { to } \\
64 \\
\end{array}$} & & 3.8 & $2,780,460$ & 4.33 & & 12 \\
\hline & & 87.8 & $64,243,260$ & 100 & & 272 \\
\hline
\end{tabular}

\section{Research Design}

For the quantitative analysis, a questionnaire type from the experimental study was used. Since conducting the survey in person was challenging due to the current Covid pandemic, the survey was be administered through Google forms. Half of the respondents were shown a CRM post and the other half was shown CS post of each of the ten selected companies Facebook messages. Following that, they were required to complete the survey forms. This study's respondents were 272 randomly chosen Facebook users aged 18 to 64 . The whole survey was conducted on the internet to ensure the validity of the research environment.

\section{Data Collection}

The research used a between-subjects configuration of two (CSR marketing communications types: CRM or CS) x two (CSR communications - brand fit: existence or absence of fit) between-subjects. A total of ten CSR updates were published on Facebook, leading to twenty CSR messages that contained both CRM and CS for each of the ten business brands. The experiment was carried out by splitting 272 active Facebook users into two groups: the first group of 136 FB users viewed and compared the companies' CSR-CRM FB posts, whilst the remaining FB users viewed the companies' CSR-CS posts. Participants in the first category, known as the CRM group ( $\mathrm{n}=136)$, and the second group, known as the CS group, viewed ten CSR posts and filled out a survey form for each post. The justification for having different groups rank CRM and CS posts was to combat order bias (Garbarski et al. 2014). 


\section{Results and Discussions}

The data review indicated statistically important variations and associations between the dependent variable (company-cause fit) and the independent variables (liking/joining FB accounts, eWOM, and purchasing intention).

\section{Contrasting CRM and CS in terms of Cosumer Responses}

This segment compared CRM and CS customer responses such as liking/joining FB sites, eWOM, purchasing intention, and company-cause fit. Mann-Whitney non-parametric test was used to distinguish variations. The significance level is set at 0.05 .

\section{Liking/Joining FB Pages}

Table 3 reveals that there is a significant difference in liking/joining FB pages between CRM and CS. The test produced a p-value of 0.000 , which is less than the necessary 0.05 degree of significance. CRM has a higher mean rank of 3501.52 than CS, which is 2979.48 . This means that CRM had a stronger effect on liking/joining Facebook pages than CS.

Table 3: Difference Between CRM and CS in Terms of Liking/Joining FB Pages

\begin{tabular}{lll}
\hline Statistical Test & P-value & Interpretation \\
\hline Mann-Whitney Test & $0.000^{*}$ & $\begin{array}{l}\text { There is a significant } \\
\text { difference }\end{array}$
\end{tabular}

* The value is less than 0.05 level of significance

\begin{tabular}{ll}
\hline & Mean Rank \\
\hline CS & 2979.48 \\
\hline CRM & $3501.52^{*}$ \\
\hline
\end{tabular}

* CRM obtained a higher reaction rate than CS.

eWoM

Table 4 indicates that there was a significant difference between CRM and CS. The test produced a p-value of 0.000 , which is less than the necessary 0.05 degree of significance.

CRM has a higher mean rank of 3479.55 than CS, which is 3001.45 . These suggest that CRM had a greater influence on eWOM.

Table 4: Difference Between CRM and CS in Terms of eWOM

\begin{tabular}{lll}
\hline Statistical Test & \multicolumn{1}{c}{ P-value } & Interpretation \\
\hline Mann-Whitney Test $0.000^{*}$ & $\begin{array}{l}\text { There is a significant } \\
\text { difference }\end{array}$ \\
& & \\
\hline The value is less than 0.05 level of significance & Mean Rank \\
\hline CS & 3001.45 & \\
\hline CRM & $3479.55^{*}$ & \\
\hline CRM obtained a higher reaction rate than CS. &
\end{tabular}

\section{Purchase Intention}

Table 5 indicates that there was a significant difference in purchase intention between CRM and CS. The test produced a p-value of 0.000 , which is less than the necessary 0.05 degree of significance. CRM had a higher mean rank of 3444.54 than CS, which is 3037.46. This suggests that CRM had a stronger influence on purchase intention than CS. 
Volume 3 Issue 8 (June 2021) PP. 98-118 DOI 10.35631/AIJBES.38007

Table 5: Difference Between CRM and CS in Terms of Purchase Intention

\begin{tabular}{lll}
\hline Statistical Test & \multicolumn{1}{c}{ P-value } & Interpretation \\
\hline Mann-Whitney Test & \multicolumn{1}{c}{$000^{*}$} & $\begin{array}{l}\text { There is a significant } \\
\text { difference }\end{array}$ \\
& & \\
\hline The value is less than 0.05 level of significance & Mean Rank \\
\hline CS & 3037.46 & \\
\hline CRM & $3444.54^{*}$ & \\
\hline CRM obtained a higher reaction rate than CS. &
\end{tabular}

\section{Company-Cause Fit}

Table 6 indicated that there was a significant difference between CRM and CS. The test produced a p-value of 0.000 , which was less than the necessary 0.05 degree of significance. CRM had a higher mean rank of 3493.64 than CS, which is 2987.36. This meant that when designing CRM articles, company-cause fit can take priority over CS.

Table 6: Difference Between CRM and CS in Terms of Company-Cause Fit

\begin{tabular}{lll}
\hline Statistical Test & P-value & Interpretation \\
\hline Mann-Whitney Test & $0.000^{*}$ & $\begin{array}{l}\text { There is a significant } \\
\text { difference }\end{array}$ \\
\hline The value is less than 0.05 level of significance & \\
\hline & Mean Rank \\
\hline CS & 2987.36 & \\
\hline CRM & $3493.64^{*}$ & \\
\hline
\end{tabular}

* CRM obtained a higher reaction rating than CS.

Overall, evidence reveals that CRM outperformed CS in all variables with a significant margin. This suggested that during pandemics, businesses can choose CRM over CS as the mode of CSR to use for FB CSR marketing communications activities.

Testing the Relationship Between CRM and CS's Company-Cause Fit and Liking/Joining FB Pages, $e$ WOM, and Purchase Intention

CRM and CS's company-cause fit, liking/sharing FB accounts, eWOM, and purchasing purpose were evaluated in this segment to see whether there was a significant difference between them. The Spearman Rank Correlation Coefficient was used as a parametric measure to validate whether or not there were any significant differences between the variables. The meaning in the table indicated whether there is a positive or negative association between the variables. The p-value defined whether or not there was a meaningful association between the factors under scrutiny.

\section{CRM Company-Cause Fit and Liking/Joining FB Pages}

According to Table 7, the meaning result is 0.698 , suggesting that there was a clear positive association between CRM company-cause fit and liking. The p-value is 0.000 , indicating that there was a statistically relevant association between CRM company-cause fit and liking/joining Facebook pages. This implied that as the number of people who like/join Facebook pages grew so will the number of people who were interested in the company's cause. 
Volume 3 Issue 8 (June 2021) PP. 98-118 DOI 10.35631/AIJBES.38007

Table 7: Relationship of CRM's Company-Cause Fit and Liking/Joining FB Pages

\begin{tabular}{llll}
\hline Statistical Test & Value & P-value & Interpretation \\
\hline $\begin{array}{l}\text { Spearman Rank } \\
\text { Correlation }\end{array}$ & $0.698^{*}$ & $0.000^{* *}$ & $\begin{array}{l}\text { There is a significant } \\
\text { relationship }\end{array}$ \\
Coefficient & & &
\end{tabular}

* The value is strong positive correlation

**The value is less than 0.05 level of significance

\section{CRM Company-Cause Fit and eWOM}

The meaning outcome in Table 8 was 0.738 , which showed a good positive association between CRM company-cause fit and eWOM. The p-value is 0.000 , suggesting that there is an important association between CRM and eWOM. This meant that as eWOM grew so would company-cause fit.

\section{Table 8: Relationship of CRM's Company-Cause Fit and eWOM}

\begin{tabular}{llll}
\hline Statistical Test & Value & P-value & Interpretation \\
\hline $\begin{array}{l}\text { Spearman Rank } \\
\text { Correlation }\end{array}$ & $0.738^{*}$ & $0.000^{* *}$ & $\begin{array}{l}\text { There is a significant } \\
\text { relationship }\end{array}$ \\
Coefficient & & & \\
\hline
\end{tabular}

$*$ The value is strong positive correlation

**The value is less than 0.05 level of significance

\section{CRM Company-Cause Fit and Purchase Intention}

The meaning result in Table 9 was 0.758 , which showed a good positive association between CRM company-cause fit and purchase intention. The p-value is 0.000 , indicating that there was a statistically meaningful association between CRM's company-cause fit and purchasing intent. This implied that as purchasing intent grows, so would company-cause fit.

Table 9: Relationship of CRM's Company-Cause Fit and Purchase Intention

\begin{tabular}{llll}
\hline Statistical Test & Value & P-value & Interpretation \\
\hline $\begin{array}{l}\text { Spearman Rank } \\
\text { Correlation }\end{array}$ & $0.758^{*}$ & $0.000^{* *}$ & $\begin{array}{l}\text { There is a significant } \\
\text { relationship }\end{array}$ \\
Coefficient & & & \\
\hline
\end{tabular}

* The value is strong positive correlation

**The value is less than 0.05 level of significance

\section{CS Company-Cause Fit and Liking/Joining FB Pages}

According to Table 10, the meaning outcome is 0.675 suggesting that there was a relatively good positive association between CS company-cause suit and liking. The p-value is 0.000 , indicating that there was a statistically meaningful association between CS's company-cause fit and liking/joining Facebook pages. This meant that as the number of people who like/join Facebook pages increases, so would the number of people who were involved in the company's cause.

Table 10: Relationship of CS's Company-Cause Fit and Liking/Joining FB Pages

\begin{tabular}{llll}
\hline Statistical Test & Value & P-value & Interpretation \\
\hline $\begin{array}{l}\text { Spearman Rank } \\
\text { Correlation }\end{array}$ & $0.675^{*}$ & $0.000^{*} *$ & There is a significant \\
relationship & \\
Coefficient & & \\
The value is strong positive correlation & & \\
Copyright $\odot$ GLOBAL ACADEMIC EXCELLENCE $(M) S D N B H D$ - All rights reserved
\end{tabular}


$* *$ The value is less than 0.05 level of significance

\section{CS Company-Cause Fit and eWOM}

Table 11 indicates that the meaning outcome is 0.750 , suggesting a good positive association between CS company-cause fit and eWOM. The p-value is 0.000 , indicating that the association between CS's company-cause fit and eWOM is important. This means that as eWOM develops, company-cause fit grows as well.

Table 11: Relationship of CS's Company-Cause Fit and eWOM

\begin{tabular}{llll}
\hline Statistical Test & Value & P-value & Interpretation \\
\hline $\begin{array}{l}\text { Spearman Rank } \\
\text { Correlation }\end{array}$ & $0.750^{*}$ & $0.000^{* *}$ & $\begin{array}{l}\text { There is a significant } \\
\text { relationship }\end{array}$ \\
Coefficient & & & \\
\hline
\end{tabular}

* The value is strong positive correlation

**The value is less than 0.05 level of significance

\section{CS Company-Cause Fit and Purchase Intention}

The meaning result in Table 12 is 0.761 , showing a good positive association between CRM company-cause fit and eWOM. The p-value is 0.000 , suggesting that there is a statistically meaningful association between CRM's company-cause fit and purchasing intent. This meant that as buying purpose rises, so would company-cause fit.

Table 12: Relationship of CS's Company-Cause Fit and Purchase Intention

\begin{tabular}{llll}
\hline Statistical Test & Value & P-value & Interpretation \\
\hline $\begin{array}{l}\text { Spearman Rank } \\
\text { Correlation }\end{array}$ & $0.761^{*}$ & $0.000^{* *}$ & $\begin{array}{l}\text { There is a significant } \\
\text { relationship }\end{array}$ \\
Coefficient & & & \\
\hline
\end{tabular}

* The value is strong positive correlation

**The value is less than 0.05 level of significance

As confirmed in the study by Liebatreau (2017), company-cause fit has direct effect on relationship between cause affinity and consumer responses toward company. In the same study, it states that company-cause fit improves attitudes toward alliances between company and customers. Furthermore, company-cause fit influences the overall attitude if the customer toward the company.

\section{Results of Hypothesis Testing}

Table 13. Result of Hypotheses Testing

\begin{tabular}{|c|c|c|c|c|c|c|}
\hline $\begin{array}{l}\text { Hypothe } \\
\text { sis }\end{array}$ & Description & The Relationship & Value (v) & $\begin{array}{c}\text { p- } \\
\text { value }\end{array}$ & $\begin{array}{l}\text { Support } \\
\text { ed }\end{array}$ & $\begin{array}{c}\text { Decisio } \\
\mathbf{n}\end{array}$ \\
\hline \multirow{7}{*}{ Ho1 } & No & CRM Liking $\rightarrow$ CS & & $0.000 *$ & \multirow{7}{*}{ Yes } & \multirow{7}{*}{$\begin{array}{c}\text { Reject } \\
\text { Ho1 }\end{array}$} \\
\hline & difference & Liking & & $0.000 *$ & & \\
\hline & between & $\mathrm{CRM}$ eWOM $\rightarrow \mathrm{CS}$ & & $0.000 *$ & & \\
\hline & CRM and CS & eWOM & & & & \\
\hline & posts on & CRM Purchase $\rightarrow$ & & & & \\
\hline & Facebook. & CS Purchase & & & & \\
\hline & & CRM Fit $\rightarrow$ CS Fit & & & & \\
\hline
\end{tabular}




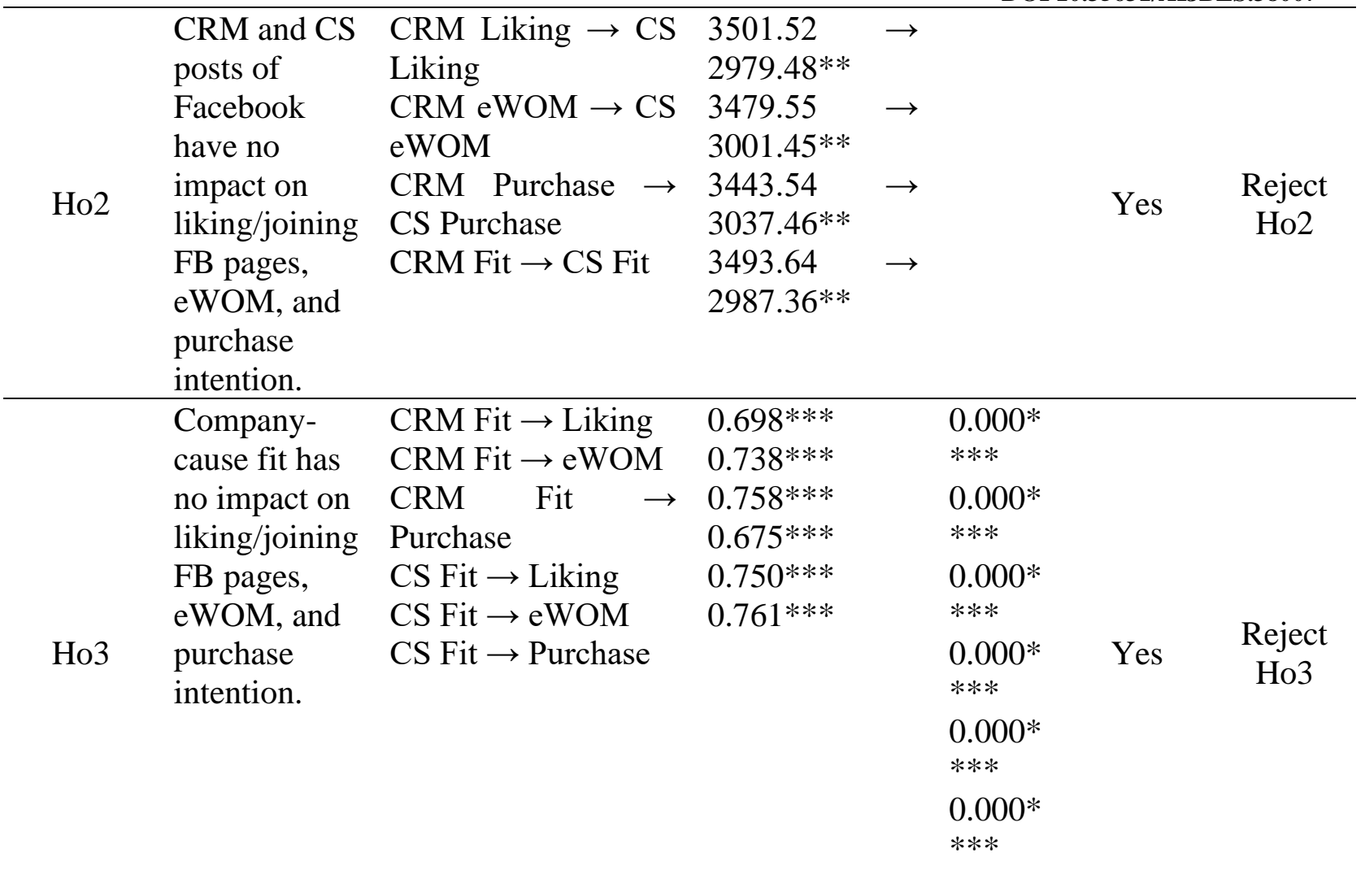

* The value is less than 0.05 level of significance

** CRM got the higher response compared to CS

*** The value is strong positive correlation

**** The value is less than 0.05 level of significance

Ho1 claimed that there is no statistically significant difference between CRM and CS posts as used in CSR marketing communications on Facebook during the Covid19 pandemic. Since the data showed a substantial gap between CRM and CS FB messages, the decision was to dismiss Ho1.

Ho2 stated there is no major impact of CRM and CS posts' company-cause fit on Facebook during the Covid19 pandemic on customers' intentions to a company in terms of liking/joining FB brand pages, eWOM purpose, and purchase intentions. Given that the data showed a substantial association between CRM and CS FB posts' company-cause fit and consumer responses, the recommendation was to dismiss Ho2.

According to Ho3, the CSR company-cause fit does not influence the impact of CSR marketing communication types on customer intentions against a company. The data provided states that company-cause fit does affect consumer responses of liking/joining brand pages, eWOM purpose, and purchase intention. As a result, the recommendation is to deny Ho3.

\section{Proposed Models for CRM and CS}

Proposed linear models were developed using Regression Analysis and Modeling techniques. These models showed the interaction between the dependent variables the independent variables in CRM and CS. 
CRM Models

Model for CRM's Company-Cause Fit and Liking

Table 14 reveals that CRM's liking has a p-value of 0.000 , far less than the degree of importance of 0.05. This suggests that CRM's company-cause fit and liking have a strong and supportive connection.

Table 14: Regression Analysis of CRM's Company-Cause Fit and Liking

\begin{tabular}{lllll}
\hline Model & $\begin{array}{l}\text { Beta } \\
\text { Coefficient }\end{array}$ & Standard Error & P-value & Interpretation \\
\hline Constant & 0.992 & 0.048 & $0.000^{*}$ & Significant \\
\hline eWoM & 0.743 & 0.011 & $0.000^{*}$ & Significant \\
\hline
\end{tabular}

*The value is less than 0.05 level of significance

Proposed Model for CRM's Company-Cause Fit and Liking:

Company-Cause Fit $=0.992+0.743 x$ Liking

According to the proposed model, with every unit rise in liking/joining FB sites, which is 0.992 or 99.2 percent, there is a 0.743 to 74.3 significant jump in company-cause fit.

\section{Model for CRM's Company-Cause Fit and eWOM}

Table 15 reveals that CRM's eWOM has a p-value of 0.000, which is less than the amount of importance of 0.05. This suggests that CRM's company-cause fit and eWOM have a substantial and supportive partnership.

Table 15: Regression Analysis of CRM's Company-Cause Fit and eWOM

\begin{tabular}{lllll}
\hline Model & $\begin{array}{l}\text { Beta } \\
\text { Coefficient }\end{array}$ & Standard Error & P-value & Interpretation \\
\hline Constant & 1.140 & 0.048 & $0.000^{*}$ & Significant \\
\hline eWoM & 0.730 & 0.011 & $0.000^{*}$ & Significant \\
\hline
\end{tabular}

*The value is less than 0.05 level of significance

Proposed Model for CRM's Company-Cause Fit and eWOM:

Company-Cause Fit $=1.140+0.730 x e W O M$

According to the proposed model, with every unit rise in eWOM, which is 1.140 or 114 percent, there is a 0.730 to 73 percent increase in company-cause fit.

\section{Model for CRM's Company-Cause Fit and Purchase Intention}

Table 16 reveals that CRM's purchase intent has a p-value of 0.000 , which is less than the amount of importance of 0.05 . This indicates that CRM's business trigger fit and buying goal have a meaningful and constructive partnership.

Table 16: Regression Analysis of CRM's Company-Cause Fit and Purchase Intention

\begin{tabular}{lllll}
\hline Model & $\begin{array}{l}\text { Beta } \\
\text { Coefficient }\end{array}$ & Standard Error & P-value & Interpretation \\
\hline Constant & 1.123 & 0.048 & $0.000^{*}$ & Significant \\
\hline eWoM & 0.738 & 0.011 & $0.000^{*}$ & Significant \\
\hline
\end{tabular}

*The value is less than 0.05 level of significance

Copyright $\odot$ GLOBAL ACADEMIC EXCELLENCE (M) SDN BHD - All rights reserved 
Proposed Model for CRM's Company-Cause Fit and Purchase Intention:

\section{Company-Cause Fit $=1.123+0.738 x$ Purchase Intention}

According to the proposed model, with any unit growth in buying intention, which is 1.123 or 123 percent, there is a 0.738 to 73.8 percent increase in company-cause fit.

Model for CRM's Company-Cause Fit, Liking/Joining FB Pages, eWOM, and Purchase Intention

Table 17 reveals that CRM's liking/joining FB accounts, eWOM, and purchasing intention both have p-values of 0.000 , which is less than the amount of relevance of 0.05 . This indicates that certain variables have a favorable and constructive association with CRM's company cause fit.

Table 17: Regression Analysis of CRM's Company-Cause Fit, Liking/Joining FB Pages, eWOM, and Purchase Intention

\begin{tabular}{lllll}
\hline Model & $\begin{array}{l}\text { Beta } \\
\text { Coefficient }\end{array}$ & Standard Error & P-value & Interpretation \\
\hline Constant & 0.455 & 0.038 & $0.000^{*}$ & Significant \\
\hline Liking & 0.356 & 0.013 & $0.000^{*}$ & Significant \\
\hline eWoM & 0.229 & 0.014 & & \\
\hline $\begin{array}{l}\text { Purchase } \\
\text { Intention }\end{array}$ & 0.308 & 0.013 & & \\
The value is less than 0.05 level of significance &
\end{tabular}

Proposed Model for CRM's Company-Cause Fit and Purchase Intention:

Company-Cause Fit $=0.455+0.356 x$ Liking $+0.229 x$ WoM $+0.308 x$ Purchase Intension

According to the proposed model, with every unit improvement in like (.013), eWOM (.014), and purchasing intention (0.013), there is a 0.356 or 35.6 percent increase in like, 0.229 or 22.9 percent increase in eWOM, and 0.308 or 30.8 percent growth in purchase intention.

\section{CS Models}

\section{Model for CS's Company-Cause Fit and Liking/Joining FB Pages}

Table 18 reveals that CS's liking has a p-value of 0.000 , which is less than the degree of importance of 0.05 . This suggests that CRM's business trigger suit and liking have a substantial and supportive connection.

Table 18: Regression Analysis of CS's Company-Cause Fit and Liking/Joining FB Pages

\begin{tabular}{lllll}
\hline Model & $\begin{array}{l}\text { Beta } \\
\text { Coefficient }\end{array}$ & Standard Error & P-value & Interpretation \\
\hline Constant & 1.202 & 0.048 & $0.000^{*}$ & Significant \\
\hline Liking & 0.682 & 0.012 & $0.000^{*}$ & Significant \\
\hline
\end{tabular}

*The value is less than 0.05 level of significance 
Proposed Model for Company-Cause Fit and Liking

Company-Cause Fit $=1.202+0.682 x$ Liking

According to the proposed model, in every unit increase in liking/joining FB sites, which is 1.202 or 120.2 percent, there is a 0.682 to 68.2 percent higher in company-cause fit.

\section{Model for CS's Company-Cause Fit and eWOM}

Table 19 revealed that CS's eWOM has a p-value of 0.000 , which is below the degree of importance of 0.05 . This indicated that CRM's company cause fit and eWOM have a significant and supportive relationship.

Table 19: Regression Analysis of CS's Company-Cause Fit and eWOM

\begin{tabular}{lllll}
\hline Model & $\begin{array}{l}\text { Beta } \\
\text { Coefficient }\end{array}$ & Standard Error & P-value & Interpretation \\
\hline Constant & 1.120 & 0.040 & $0.000^{*}$ & Significant \\
\hline eWoM & 0.723 & 0.010 & $0.000^{*}$ & Significant \\
\hline
\end{tabular}

*The value is less than 0.05 level of significance

Proposed Model for Company-Cause Fit and eWOM

\section{Company Cause Fit $=1.120+0.723 x e$ WoM}

According to the proposed model, with every unit rise in eWOM, which is 1.12 or 112 percent, there was a 0.723 to 72.3 percent increase in company-cause fit.

\section{Model for CS's Company-Cause Fit and Purchase Intention}

Table 20 revealed that CS's purchase intention has a p-value of 0.000 , which is less than the amount of significance of 0.05 . This suggested that CRM's company cause fit has a significant and supportive connection.

Table 20: Regression Analysis of CS's Company-Cause Fit and Purchase Intention

\begin{tabular}{lllll}
\hline Model & $\begin{array}{l}\text { Beta } \\
\text { Coefficient }\end{array}$ & Standard Error & P-value & Interpretation \\
\hline Constant & 1.142 & 0.038 & $0.000^{*}$ & Significant \\
\hline eWoM & 0.717 & 0.010 & $0.000^{*}$ & Significant \\
\hline
\end{tabular}

*The value is less than 0.05 level of significance

Proposed Model for CS's Company-Cause Fit and Purchase Intention:

\section{Company Cause Fit $=1.142+0.717 x$ Purchase Intention}

According to the proposed model, with every unit rise in purchase intention, which is 1.14 or 114 percent, there was a 0.717 to 71.7 percent increase in company-cause fit.

\section{Model for CS's Company-Cause Fit, Liking/Joining FB Pages, eWOM, and Purchase Intention}

Table 21 revealed that CRM's p-values for liking/joining FB accounts, eWOM, and purchase intention are all less than 0.000 , which is less than the amount of relevance of 0.05 . This indicated that certain variables have a significant and positive association with CRM's company cause fit. 
Volume 3 Issue 8 (June 2021) PP. 98-118 DOI 10.35631/AIJBES.38007

Table 21: Regression Analysis of CS's Company-Cause Fit Liking/Joining FB Pages, eWOM, and Purchase Intention

\begin{tabular}{lllll}
\hline Model & $\begin{array}{l}\text { Beta } \\
\text { Coefficient }\end{array}$ & Standard Error & P-value & Interpretation \\
\hline Constant & 0.470 & 0.038 & $0.000^{*}$ & Significant \\
\hline Liking & 0.247 & 0.012 & $0.000^{*}$ & Significant \\
\hline eWoM & 0.308 & 0.014 & $0.000^{*}$ & Significant \\
\hline $\begin{array}{l}\text { Purchase } \\
\text { Intention }\end{array}$ & 0.329 & 0.014 & $0.000^{*}$ & Significant \\
\hline
\end{tabular}

*The value is less than 0.05 level of significance

Proposed Model for CS's Company-Cause Fit, Liking/Joining Brand Pages, eWOM, and Purchase Intention:

\section{$C C F=0.470+0.247 x$ Liking $+0.308 x$ WoM $+0.329 x$ Purchase Intention}

According to the proposed model, with every unit rise in like (.012), eWOM (.014), and purchasing intention (.014), there is a 0.247 or 24.7 percent increase in liking, 0.308 or 30.8 percent increase in eWOM, and 0.329 or 32.9 percent increase in purchase intention.

\section{Conclusions and Recommendations}

The findings of evaluating substantial relationships between CRM and CS's company-cause fit and customer responses like/sharing FB accounts, eWOM, and purchasing intention showed that both of these variables had a favorable connection. This implied that if an organization needs to improve the probability of company-cause fit, it may do so by growing any of the consumer response variables individually or by increasing all consumer response variables simultaneously. Since this was a clear and constructive partnership, it is therefore right to conclude that if a business wishes to maximize the probability of viewers liking/joining FB accounts, eWOM, and purchase intention, they can first improve their brand-cause fit. Increasing any of the variables caused the other variables to rise as well.

The proposed models demonstrated the same linear and constructive relationship as the testing significant relationships section. This meant that increasing one unit of company-cause fit, either CRM or CS, would lead to better outcomes in the customer reaction variables individually or as a collective. Any rise in company-cause fit would lead to an increase in the other consumer response variables.

As guidance for businesses, CRM marketing communications can indeed be prioritized when developing CSR plans for pandemics, but company-cause fit must be well planned in order to reap the benefits of consumer responses. No matter what type of CSR marketing communications an organization prefers, any genuine assistance from them would be deeply appreciated by their stakeholders. After all, the aim of every CSR operation is to have a good image of the business through real and genuine altruism in order to keep stakeholders satisfied.

\section{References}

Abner, M. (2019). Effects of Social Media, Electronic Word-of-Mouth, and Price on U.S. Female Consumers' Attitude Toward Purchase and Purchase Intention of Ethical Apparel.

Beise-Zee, R. (2013). Cause Related Marketing. Encyclopedia of Corporate Social Responsibility, pp. 321-326. 
Bigné, E., Pérez, R. \& Aldás-Manzano, J. (2012). Dual Nature of Cause-Brand Fit: Influence on Corporate Social Responsibility Consumer Perception. European Journal of Marketing, 46. 575-594.

Bryum, K. (2014). A Comparison of the Source Media, Media Format, and Sentiment in Generating Source Credibility, Information Credibility, Corporate Brand Reputation, Purchase Intention, and Social Media Engagement in a Corporate Social Responsibility Campaign Presented Via Social Media. Clemson University, South Carolina

Chang, C. (2012). The Effectiveness of Advertising That Leverages Sponsorship and CauseRelated Marketing: A Contingency Model. International Journal of Advertising, 31(2), 317-338.

Chung, A.(2019). A Test of the Hierarchy of the Advertising Effects via a Panel Data Set on Email Advertising. University of Texas, Texas.

Colleoni, E. (2013). "CSR Communication Strategies for Organizational Legitimacy in Social Media", Corporate Communications: An International Journal, 18(2): pp. 228-248.

Curley, C. B., \& Noormohamed, N. A. (2014). Social Media Marketing Effects on Corporate Social Responsibility. Journal of Business \& Economics Research (Online), 12(1), 61n/a.

Retrieved

from http://search.proquest.com.proxy1.ncu.edu/docview/1477975396?accountid=28180

Erkan, I. (2016). The Influence of Electronic Word of Mouth in Social Media on Consumers' Purchase Intentions. Brunel University, London

Esen, E. \& Ozsozgun, A (2018). Sustainability Disclosures and Impression Management o, Social Media, Pressacademia, 7(1):213-216

Fatma, M., Pérez, A, Khan, I., Rahman. Z. (2020). The Effect of CSR Engagement on eWOM on Social Media. International Journal of Organizational, Vol. 28 No. 4: pp. 941-956

Garbarski, D., Schaeffer, N., \&Dykema, J. (2014). The Effects of Response Order on SelfRated Health. Quality of Life Research, 24(6): pp. 1443-1453.

He, H. \& Harris, L. (2020). The Impact of Covid-19 Pandemic on Corporate Social Responsibility and Marketing Philosophy. Journal of Business Research, 116: 176-182.

Human, D. (2016). The Influence of Cause Related Marketing Campaign Structural Elements on Consumer Intention, Attitude and Perception. Stellenbosch University, South Africa

Jeong, H.J. (2011), “The Effectiveness of Corporate Social Responsibility (CSR) Campaigns on Consumer Responses to Brands in Social Media: Impression Management Perspectives", Michigan State University, Michigan

Jeong, H.J., Paek, H.J. and Lee, M. (2013), "Corporate Social Responsibility Effects on Social Network Sites", Journal of Business Research, Vol. 66 No. 10: 1889-1895.

Kim, K., Cheong, Y. \& Lim, J. (2015). Choosing the right message for the right cause in social cause advertising: type of social cause message, perceived company-cause fit and the persuasiveness of communication, International Journal of Advertising, 34:3, 473-494

Kitzmueller, M. \& Shimshack, J. (2012). Economic Perspectives on Corporate Social Responsibility. Journal of Economics Literature, 50(1): 51-84

Lee, K. T., \& Koo, D. M. (2015). Evaluating Right Versus Just Evaluating Online Consumer Reviews. Computers in Human Behavior, 45, 316-327.

Lee, S Y., Zhang, W. \& Abitbol, A. (2019). What Makes CSR Communication Lead to CSR Participation? Testing the Mediating Effects of CSR Associations, CSR Credibility, and Organization-Public Relationships. Journal of Business Ethics, 157 (2):413-429

Liebatreau, J. (2017). Toward Developing a Model for Fit in Cause-Related Marketing. University of Lethbridge, Alberta, Canada 
Volume 3 Issue 8 (June 2021) PP. 98-118

DOI 10.35631/AIJBES.38007

Mariam, S. \& Nisar, Q. (2016). Do Corporate Social Responsibility and Electronic Wprd-ofMouth Influence the Perceived Quality and Mediating Role of Brand Image?. Journal of Management Info, 11(1). 53-70

Markova, I \& Rosenberger, T. (2013). Effectiveness of Official Event Sponsorship. Karlstad Business School, Sweden

Martinez, P., Herrero, A. \& De Los Salmones (2020). Determinants of eWOM on Hospitality CSR Issues. In Facebook We Trust? Journal of Sustainable Tourism, Volume 28, 2020 - Issue 1o, pp. 1479-149

McDonald, L. \& Lai, C (2011). Impact of Corporate Social Responsibility Initiatives on Taiwanese Bank Customers. International Journal of Bank Marketing, Vol. 29 (1), pp. 50-63.

Mohammed, M., Khalifa G., Aziz, W., \& Mayouf, M. (2015). Determinants of Electronic Word of Mouth (EWOM) Influence on Hotel Customers' Purchasing Decision. Journal of Faculty of Tourism and Hotels, Vol. (9), No. (2/2)

Ozsozgun Caliskan, Arzu \& Esen, Emel. (2018). Sustainability Disclosures and Impression Management on Social Media. Pressacademia. $7 . \quad 213-216$. 10.17261/Pressacademia.2018.883.

Perez, A, \& del Bosque, I. (2014). An Integrative Framework to Understand How CSR Affects Customer Loyalty Through Identification, Emotions, and Satisfaction. Journal of Business Ethics

Serra, A., \& Salbi, F. (2014). New consumer behavior: A review of research on eWOM and hotels. International Journal of Hospitality Management, 26, 41-51.

Sheikh, S., \& Beise-Zee, R. (2011). Corporate Social Responsibility or Cause-Related Marketing? The Role of Cause Specificity of CSR. Journal of Consumer Marketing, 28(1), 27-39.

Statistica.com (2019). https://www.statista.com/statistics/490455/number-of-philippinesfacebook-users/

Sun, Y., Zhang, W., \& Abitbol, A., 2019. What Makes Csr Communication Lead To CSR Participation? Testing The Mediating Effects Of Csr Associations, CSR Credibility, And Organization-Public Relationships. Journal of Business Ethics. 157 (2):413-429

Tata, J. \& Prasad, S. (2014). CSR Communication: An Impression Management Perspective. Journal of Business Ethics, (2015) 132:765-778

Türkel S., Akan A. (2015) Corporate Social Responsibility (CSR) Communication: A Turkish Industry Example. In: Kitchen P.J., Uzunoğlu E. Integrated Communications in the Postmodern Era. Palgrave Macmillan, London.

Zasuwa, G. (2017). The Role of Company-Cause Fit and Company Involvement in Consumer Responses to CSR Initiatives: A Meta-Analytic Review. The John Paul II Catholic University of Lublin, Poland 